Yalçın Baş, Göknur Kalkan, Havva Yıldız Seçkin, Zennure Takcl, Şafak Şahin*, Ayşe Kevser Demir*

\section{Geriatrik Hastalarda Dermatolojik Sorunların Analizi}

\author{
Analysis of Dermatologic Problems in \\ Geriatric Patients
}

Gaziosmanpaşa Üniversitesi

Tıp Fakültesi, Deri ve Zührevi Hastalıkları Anabilim Dalı,

Tokat, Türkiye

*Gaziosmanpaşa Üniversitesi Tıp Fakültesi, Dahiliye Anabilim Dalı, Tokat, Türkiye

\section{Yazışma Adresi/}

Correspondence:

Yalçın Baş,

Gaziosmanpaşa Üniversitesi Tıp Fakültesi, Deri ve Zührevi

Hastalıkları Anabilim Dalı, Tokat, Türkiye

E-posta: dryalcinbas@gmail.com Geliş Tarihi/Submitted: 01.11.2013 Kabul Tarihi/Accepted: 04.11.2013

@Telif Hakkı 2014 Türk Dermatoloji Derneği Makale metnine www. turkdermatolojidergisi.com web sayfasından ulaşılabilir.

@ Copyright 2014 by Turkish Society of Dermatology - Available on-line at www.turkdermatolojidergisi.com

\section{Özet}

Amaç: Tüm dünyada yaşlıların genel nüfusa oranı giderek artmaktadır. Sağlık hizmetlerinin planlanmasında bu popülasyona yönelik epidemiyolojik çalışmalar yol gösterici olacaktır.

Yöntem: 2005-2013 yılları arasında başvuran toplam 2734 yaşlı hasta analiz edildi. Veri toplamak için hastane tabanlı hasta kayıtları kullanıldı. Tespit edilen deri hastalıkları 26 grupta incelendi. Veriler yaş, cinsiyet ve mevsime göre değerlendirildi.

Bulgular: Çalışma grubuna dahil edilen toplam 2734 hastanın 1519' $v$ erkek $(\% 55,6), 1215^{\prime}$ 'i

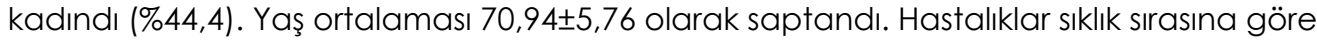
incelendiğinde ilk beş grup sırasıyla; ekzemalar (\%20,5), fungal deri hastalıkları (\%18), pruritus $(\% 12,8)$, eritemli-skuamlı hastalıklar $(\% 6,7)$ ve viral deri hastalıkları $(\% 5,4)$ olarak tespit edildi.

Sonuç: Bu çalışma yaşlı hastalarda dermatolojik hastalıkların sıklığı hakkında önemli veriler sağlar ve ayrıca yaş, cinsiyet ve mevsime göre sıklığın değiştiğini gösterir. Biz bu çalışmanın yaşlı hastalarda dermatolojik sorunların kapsamı ve biçimleri hakkında farkındalık yaratacağına inanıyoruz.

Anahtar kelimeler: Deri hastalıkları, dermatoloji, ekzema, geriatri, mevsim, pruritus

\section{Abstract}

Objective: All over the world, the proportion of elderly in general population tends to increase. Epidemiological studies concerning this part of the population will be guiding while planning health services.

Methods: Data of a total of 2734 geriatric patients admitted between the years 2005-2013 were analyzed. Hospital-based patient registry records were used for data collection. Patients were classified into 26 different groups in terms of types of their cutaneous diseases. The data were analyzed according to age, gender, and season. Results: Among 2734 patients included in the study, 1519 were males $(55.6 \%)$ and 1215 $(44.4 \%)$ were females. Mean age was $70.94 \pm 5.76$ years. When analyzed in decreasing order of incidence, the first five groups were eczema (20.5\%), fungal skin diseases (18\%), pruritus (12.8\%), erythematous-squamous disease (6.7\%), and viral skin diseases (5.4\%). Conclusions: This study provides important data on the frequency of dermatologic diseases in elderly patients, and also shows variations in the frequency depending on age, gender, and season. We believe that this study will create awareness about the extent and patterns of dermatologic problems in geriatric patients.

Key words: Skin diseases, dermatology, eczema, geriatrics, seasons, pruritus 


\section{Giriş}

Geriatrik yaş grubu hastalar 65 yaş ve üzerindeki hastalar olarak kabul edilmektedir. Gelişen dünyada modern hayatın getirdiği zorluklarla beraber doğurganlık hızının azalması; ancak buna karşın beklenen yaşam süresinin uzaması yaşlı popülasyonun nüfustaki oranının giderek artması sonucunu doğurmuştur. Ülkemizde de benzer bir nüfus dağılımı meydana gelmektedir. Türkiye İstatistik Kurumu'nun adrese dayalı nüfus kayıt sistemi 2012 yılı verilerine göre ülkemizde toplam genel nüfus 75627 384 (\%50,19 erkek, \%49,81 kadın), 65 yaş ve üzeri nüfus 5682003 (\%43,54 erkek, \%56,46 kadın) olarak tespit edilmiştir. Bu verilere göre toplam nüfusun \%7,5'i 65 yaş ve üzerindedir. Ancak Türkiye İstatistik Kurumu'nun 1935 yılı genel nüfus sayımına göre bu oran \%3,88 düzeyindedir (1). Sonuçlar geriatrik nüfus oranının artışıyla beraber ileri yaşlara bağlı deri değişiklikleri ve hastalıklarında artışı ve dolayısıyla hem dermatologların hem de diğer hekimlerin dermatolojik sorunları olan geriatrik hastalarla daha sık karşılaşacaklarını göstermektedir.

Yaşlı popülasyonla ilgili yapılacak epidemiyolojik çalışmalar geriatrik yaş grubu hastalara verilecek sağlık hizmetlerinin planlanmasında ve koruyucu sağlık hizmetlerinin geliştirilmesinde yol gösterici olacaktır. Çalışmamızda bu amaçla hastanemiz dermatoloji polikliniğinde muayene edilen 65 yaş ve üzeri hastalarda saptanan deri hastalıklarının tipleri ve bu hastalıkların cinsiyete, yaş grubuna ve mevsimlere göre dağılımları retrospektif olarak araştırıldı.

\section{Yöntemler}

Eylül 2005 ile Ocak 2013 tarihleri arasında hastanemiz dermatoloji polikliniğine başvuran 65 yaş ve üzerindeki 2734 kişi çalışmaya dahil edildi. Bu hastalar yaş, cinsiyet ve polikliniğimize başvurma mevsimine göre değerlendirildi. Hastalar yaşına göre 65-74, 75-84, 85 ve üzeri olarak gruplandırıldı. Hastalıklar kserozis, pruritus, ekzemalar, viral deri hastalıkları, bakteriyel deri hastalıkları, fungal deri hastalıkları, paraziter deri hastalıkları, vezikülobüllöz otoimmün hastalıklar, akneiform hastalıklar, kutane lenfomalar, eritemli-skuamlı hastalıklar, benign neoplazi ve nevüsler, malign neoplaziler, prekanseröz lezyonlar, bağ dokusu hastalıkları, saç hastalıkları, tırnak hastalıkları, ürtiker ve anjiyoödem, vasküler hastalıklar, fotosensitif dermatozlar, Behçet sendromu, oral mukoza hastalıkları, fiziksel etkenlere bağlı dermatozlar, pigmentasyon bozuklukları, kutanöz ilaç reaksiyonları ve diğer olmak üzere 26 grupta kategorize edildi.

Saptanan verilerin analizi için SPSS versiyon 15.0 bilgisayar programından faydalanıldı.

\section{Bulgular}

Altmış beş yaş ve üzerindeki 2734 geriatrik hastanın $\% 55,6$ 'sı erkek (1519), \%44,4'ü kadın (1215) olarak bulundu. Kadın/ erkek oranı 0,8, 65-74 yaş arası olgu sayısı 2060 (\%75,3), 75-84 yaş arası olgu sayısı 609 (\%22,3), 85 yaş ve üzeri olgu sayısı

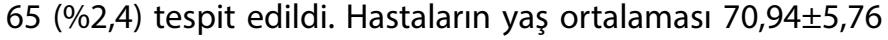
olarak bulundu. Yaş gruplarının cinsiyete göre dağılımı Tablo 1 'de görülmektedir.
Genel olarak hastalık gruplarına bakıldığında ekzemalar $(\% 20,5)$, fungal deri hastalıkları (\%18), pruritus $(\% 12,8)$, eritemli-skuamlı hastalıklar $(\% 6,7)$ ve viral deri hastalıkları $(\% 5,4)$ daha sık bulunmuştur (Tablo 2). Tüm infeksiyonlar (fungal, bakteriyel ve viral) \%27,4 ile en sık görülen gruptur. İnfeksiyonlar, ekzemalar, eritemli-skuamlı hastalıklar, pruritus ve kseroderma hastalık gruplarının beş tanesi \%71,1 oranındadır. En sık görülen ekzema tipleri kontakt dermatit $(\% 35,5)$, kserotik ekzema $(\% 12,2)$, numuler dermatit $(\% 10,6)$, nörodermatit $(\% 9,5)$, eritema intertrigo $(\% 4,3)$ olarak bulundu. En sık görülen fungal infeksiyonlar tinea pedis (\%43), tinea ungium $(\% 38,5)$, tinea corporis $(\% 6,3)$, tinea cruris $(\% 5,5)$, tinea versikolor $(\% 3)$, tinea manum $(\% 2,4)$ olarak tespit edildi. En sık görülen eritemli-skuamlı hastalıklar psoriyazis $(\% 45,7)$, seboreik dermatit $(\% 29,9)$, likenoid erüpsiyonlar $(\% 23,4)$ olarak bulundu. En sık görülen viral hastalıklar herpes zoster (\%47), verrüler (\%47), herpes simplex virüs infeksiyonları (\%6) olarak bulundu (Tablo 3).

Cinsiyete göre hastalık gruplarına bakıldığında kadınlarda en sık ekzemalar $(\% 19,8)$, fungal deri hastalıkları $(\% 15,6)$, pruritus $(\% 13,1)$, eritemli-skuamlı hastalıklar $(\% 6,5)$, ürtiker ve anjiyoödem $(\% 5,3)$; erkeklerde en sık ekzemalar $(\% 21,1)$, fungal deri hastalıkları (\%20), pruritus (\%12,5), eritemliskuamlı hastalıklar $(\% 6,9)$, viral deri hastalıkları $(\% 6,1)$ olarak tespit edildi (Tablo 2).

Üç farklı yaş grubuna göre hastalık gruplarına bakıldığında 6574 yaş arasında en sık ekzemalar (\%20), fungal deri hastalıkları $(\% 19,4)$, pruritus $(\% 12,2)$, eritemli-skuamlı hastalıklar $(\% 7,9)$, viral deri hastalıkları $(\% 5,2)$; $75-84$ yaş arasında en sık ekzemalar (\%21,8), pruritus $(\% 14,3)$, fungal deri hastalıkları $(\% 13,6)$, viral deri hastalıkları $(\% 6,2)$, prekanseröz lezyonlar $(\% 6,1) ; 85$ yaş ve üzerinde en sık ekzemalar $(\% 23,1)$, pruritus $(\% 16,9)$, fungal deri hastalıkları $(\% 15,4)$, bakteriyel deri hastalıkları $(\% 13,8)$ olarak tespit edilmiştir (Tablo 4).

Mevsimlere göre hastalık gruplarına bakıldığında kış aylarında en sık ekzemalar (\%20,3), pruritus (\%17), fungal deri hastalıkları (\%14,8), eritemli-skuamlı hastalıklar (\%8), viral deri hastalıkları $(\% 5,7)$; ilkbahar aylarında en sık fungal deri hastalıkları $(\% 19,4)$, ekzemalar $(\% 18,6)$, pruritus $(\% 11,7)$, eritemli-skuamlı hastalıklar $(\% 7,3)$, viral deri hastalıkları $(\% 6,2)$; yaz aylarında en sık ekzemalar $(\% 20,8)$, fungal deri hastalıkları $(\% 20,2)$, pruritus $(\% 9,9)$, eritemli-skuamlı hastalıklar $(\% 6,1)$, viral deri hastalıkları $(\% 5,3)$; sonbahar aylarında en sık ekzemalar $(\% 22,4)$, fungal deri hastalıkları $(\% 17,2)$, pruritus $(\% 13,1)$, kserozis $(\% 7,1)$, eritemli skuamlı hastalıklar $(\% 5,7)$ olarak tespit edildi (Tablo 5). Kserozis ve pruritus ilkbahar-yaz mevsimlerinde azalırken; sonbahar-kış aylarında ise arttığı saptandı. Fungal deri hastalıkları, akneiform hastalıklar ve fotosensitif dermatozların ilkbahar-yaz aylarında arttığı; sonbahar-kış aylarında ise azaldığı tespit edildi.

\section{Tablo 1. Yaş gruplarının cinsiyete göre dağılımı}

\begin{tabular}{|l|l|l|l|l|l|l|l|l|}
\hline \multirow{2}{*}{ Cinsiyet } & \multicolumn{2}{|l|}{$\mathbf{6 5 - 7 4}$ Yaş } & \multicolumn{2}{|c|}{$\mathbf{7 5 - 8 4}$ Yaş } & \multicolumn{2}{|c|}{ 85 ve Üzeri Yaş } & \multicolumn{2}{|c|}{ Toplam } \\
\cline { 2 - 9 } & $\mathbf{n}$ & $\mathbf{\%}$ & $\mathbf{n}$ & $\mathbf{\%}$ & $\mathbf{n}$ & $\mathbf{\%}$ & $\mathbf{n}$ & $\mathbf{\%}$ \\
\hline Kadın & 936 & 77,0 & 244 & 20,1 & 35 & 2,9 & 1215 & 100 \\
\hline Erkek & 1124 & 74,0 & 365 & 24,0 & 30 & 2,0 & 1519 & 100 \\
\hline Toplam & 2060 & 75,3 & 609 & 22,3 & 65 & 2,4 & 2734 & 100 \\
\hline
\end{tabular}




\section{Tartışma}

Yaşlı nüfusun toplumda ki oranı giderek artmaktadır. Türkiye İstatistik Kurumu'nun adrese dayalı nüfus kayıt sistemi 2012 yılı verilerine göre ülkemizde toplam genel nüfus 75627384 (\%50,19 erkek, \%49,81 kadın), 65 yaş ve üzeri nüfus 5682 003 (\%43,54 erkek, \%56,46 kadın) olarak tespit edilmiştir. $\mathrm{Bu}$ verilere göre toplam nüfusun $\% 7,565$ yaş ve üzerindedir.
Ancak Türkiye İstatistik Kurumu'nun 1935 yılı genel nüfus sayımına göre bu oran \%3,88 düzeyindedir (1). Sonuç olarak ilerleyen yıllarda geriatrik hastaların klinik hastalarımızın önemli bir bölümünü oluşturacağı tahmin edilebilir.

Geriatrik hastalarda sık görülen nörolojik defisitler, immün fonksiyonlarda bozulma, şişmanlık, malnütrüsyon, epidermal hücre yenilenmesinde yavaşlama ve özellikle günlük kişisel

\section{Tablo 2. Yaşı hastalarda cilt hastalıklarının cinsiyete göre dağılımı}

\begin{tabular}{|c|c|c|c|c|c|c|}
\hline \multirow[t]{2}{*}{ Hastalık grubu } & \multicolumn{2}{|c|}{ Kadın } & \multicolumn{2}{|c|}{ Erkek } & \multicolumn{2}{|c|}{ Toplam } \\
\hline & $\mathbf{n}$ & $\%$ & n & $\%$ & $\mathbf{n}$ & $\%$ \\
\hline Kserozis & 47 & 3,9 & 53 & 3,5 & 100 & 3,7 \\
\hline Ekzemalar & 241 & 19,8 & 320 & 21,1 & 561 & 20,5 \\
\hline Viral deri hastalıkları & 56 & 4,6 & 93 & 6,1 & 149 & 5,4 \\
\hline Fungal deri hastalıkları & 189 & 15,6 & 304 & 20,0 & 493 & 18,0 \\
\hline Paraziter deri hastalıkları & 38 & 3,1 & 20 & 1,3 & 58 & 2,1 \\
\hline Vezikülobüllöz hastalıklar & 17 & 1,4 & 4 & 0,3 & 21 & 0,8 \\
\hline Akneiform hastalıklar & 23 & 1,9 & 50 & 3,3 & 73 & 2,7 \\
\hline Malign neoplaziler & 22 & 1,8 & 29 & 1,9 & 51 & 1,9 \\
\hline Prekanseröz lezyonlar & 47 & 3,9 & 62 & 4,1 & 109 & 4,0 \\
\hline Bağ dokusu hastalıkları & 8 & 0,7 & 8 & 0,5 & 16 & 0,6 \\
\hline Saç hastalıkları & 4 & 0,3 & 1 & 0,1 & 5 & 0,2 \\
\hline Tirnak hastalıkları & 4 & 0,3 & 3 & 0,2 & 7 & 0,3 \\
\hline Ürtiker ve anjiyoödem & 64 & 5,3 & 40 & 2,6 & 104 & 3,8 \\
\hline Vasküler hastalıklar & 19 & 1,6 & 21 & 1,4 & 40 & 1,5 \\
\hline Fotosensitif dermatozlar & 5 & 0,4 & 4 & 0,3 & 9 & 0,3 \\
\hline Behçet Sendromu & 6 & 0,5 & 0 & 0,0 & 6 & 0,2 \\
\hline Toplam & 1215 & 100 & 1519 & 100 & 2734 & 100 \\
\hline
\end{tabular}

Tablo 3. Sık görülen hastalık gruplarının detaylı incelenmesi

\begin{tabular}{|l|l|l|l|l|l|l|l|}
\hline \multicolumn{3}{|l|}{ Ekzemalar } & \multicolumn{2}{l|}{ Fungal deri hastalıkları } & \multicolumn{2}{l|}{ Eritemli-skuamlı hastalıklar } & \multicolumn{2}{l|}{ Viral deri hastalıları } \\
\hline Kontakt dermatit & $\% 35,5$ & Tinea pedis & $\% 43$ & Psoriyazis & $\% 45,7$ & Herpes zoster & $\% 47$ \\
\hline Kserotik ekzema & $\% 12,2$ & Tinea ungium & $\% 38,5$ & Seboreik dermatit & $\% 29,9$ & Verrüler & $\% 47$ \\
\hline Numuler dermatit & $\% 10,6$ & Tinea corporis & $\% 6,3$ & Likenoid erüpsiyonlar & $\% 23,4$ & Herpes simplex & $\% 6$ \\
\hline Nörodermatit & $\% 9,5$ & Tinea cruris & $\% 5,5$ & Diğer & $\% 1,1$ & & \\
\hline Eritema intertirigo & $\% 4,3$ & Tinea versikolor & $\% 3$ & & & & \\
\hline Diğer ve tanımlanmamış & $\% 27,8$ & Diğer & $\% 3,6$ & & & & \\
\hline
\end{tabular}


bakımda yetersizlikler nedeniyle infeksiyon hastalıklarının görülme olasılığı artmıştır (2-4). Araştırmada genel olarak hastalık gruplarına bakıldığında birçok çalışmada olduğu gibi en sık $(\% 27,4)$ infeksiyon hastalıkları bulundu $(5-7)$. Tek başına yüzeysel mantar hastalıklarının tüm hastalık grupları içinde $\% 18$ oranında görülmesi dikkat çekicidir. Ayrıca bu mantar infeksiyonlarının \%81,5 ayak bölgesine lokalizedir [tinea pedis (\%43), tinea ungium $(\% 38,5)]$. Ayakların yıkandıktan sonra kurulanmaması, yaz aylarında bile kalın ve çok sayıda çorap giyilmesinin uygun ortam sağladığı düşüncesindeyiz. Viral hastalık grubunda ise en sık bulunan zona zoster (\%47) akut dönemdeki ağrısıyla yerleştiği bölgeye göre apandisit, böbrek taşı, kalp krizi gibi ağrılı hastalıklarla karışabilir. Kronik dönemde postherpetik nevralji özellikle yaşlı hastalarda aylarca devam ederek kişinin yaşam kalitesini önemli derecede etkileyebilir. Antiviral tedaviyle hastalık yayılımının durduğu ve kronik ağrı süresinin kısaldığı bilinmektedir. Bu yüzden yaşlı hastalarda ilk 72 saat içinde antiviral tedavi başlanmalıdır (8).
Yaşlı hastalarda yıllar içinde deri daha kuru ve kaşıntılı hale gelmektedir. Çok sayıda etken deride kaşıntı yapmasına rağmen yaşlılarda kserozis en önemli nedenlerden biridir (9). Bizim çalışmamızda pruritus $\% 12,8$ ile ülkemizde yapılan çalışmalara göre yüksek bulunmuştur $(6,7,10)$. Kserozis ise $\% 3,7$ olarak düşük oranda tespit edilmiştir. Geriatrik hastaların $\% 75$ 'inde kserozis bulunduğu düşünülmektedir (11). Yaşlı hastalarda kserozis pruritusun önemli ve sık görülen nedenlerindendir. Aslında hastalar pruritustan yakındıklarında bir çoğunda kserozisin olabileceği de dikkate alınmalıdır. Çalışmada verilerin retrospektif olması nedeniyle hastanın şikayeti yoksa tanının girilmediği ve elde edilen sonucun aksine bölgemizde de yaşlı hastalarda kserozisin daha yüksek olduğunu düşünmekteyiz. Farklı bölgelerde yapılsa da bizim düşüncemizi destekleyen ülkemizde yapılan prospektif çalışmalar mevcuttur $(12,13)$.

Ekzemalar \%20,5 ile hastalık grupları içinde en sık görüleni olarak bulundu. Kontakt dermatitler bu grup içinde en yaygın dermatit tipi ve ikinci sıklıkta kserotik ekzema tespit

\section{Tablo 4. Yaşlı hastalarda yaş gruplarına göre cilt hastalıklarının dağılımı}

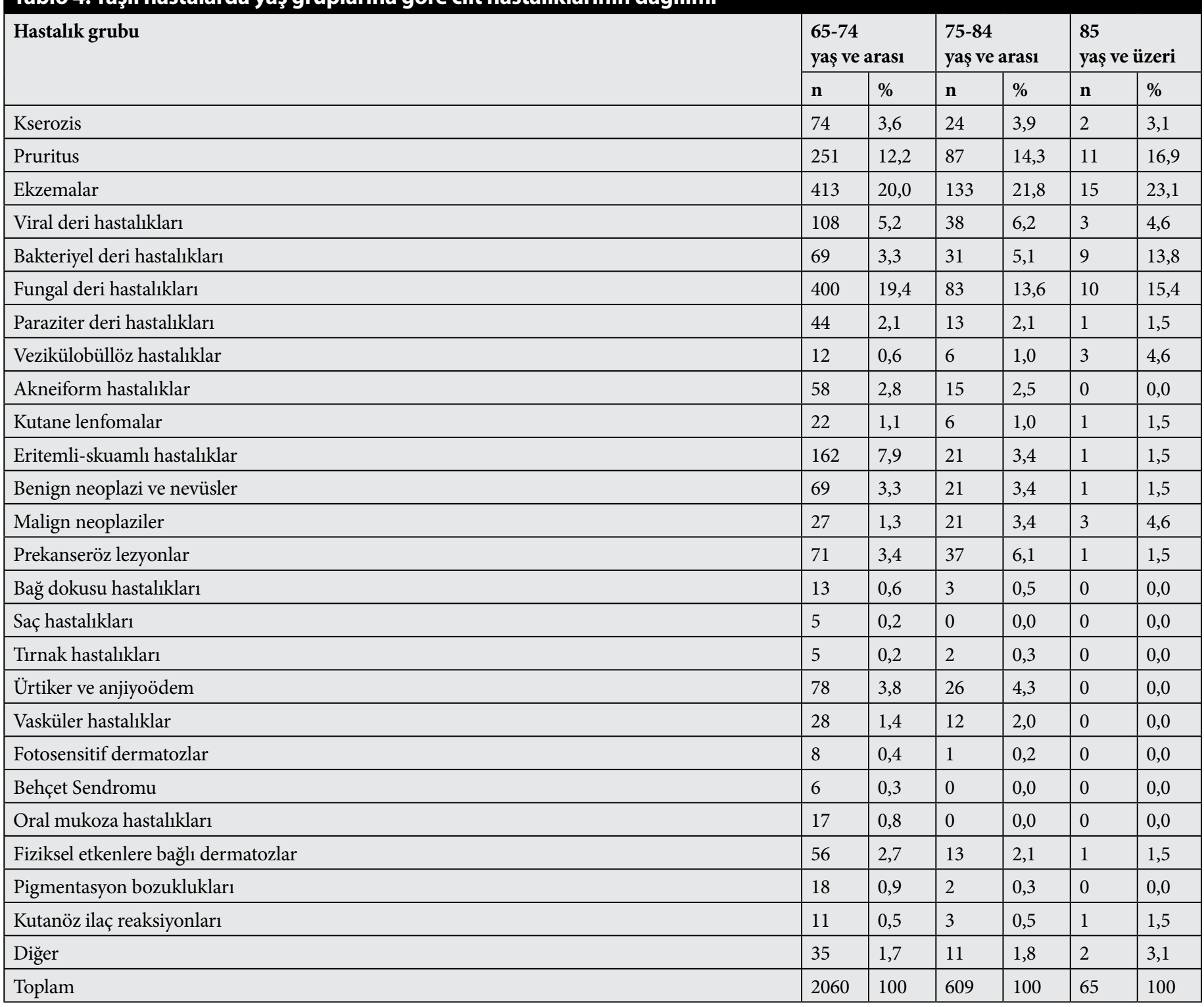


edildi. Çoğu çalışmada ekzemalar yaşlı hastalarda sık görülen hastalık grupları içinde bulunmuştur $(5,6,7,14)$. Yine kserozisin kserotik ekzema ve diğer ekzemalar içinde önemli bir faktör olduğu bilinmektedir.

Yaşı ı hastalarda cinsiyete göre hastalık gruplarına bakıldığında daha sık görülen hastalıklar ve oranları birbirine yakındır. Ancak kadınlarda vezikülobüllöz otoimmün hastalıklar ve ürtiker-anjioödem daha sık iken; erkek hastalarda infeksiyon hastalıkları ve akneiform hastalıklar daha sık bulunmuştur. Vezikülobülloz hastalıklar toplumda eşit sıklıkta bulunmasına rağmen bizim çalışmamızda kadınlarda yüksek olmasının nedeni açık değildir (15). Ayrıca benzer bir çalışmada vezikülobüllöz hastalıklar bizim çalışmanın aksine erkeklerde daha sık bulunmuştur (10).

Yaşı hastalarda yaş gruplarına göre hastalık gruplarına bakıldığında daha sık görülen hastalıklar ve oranları birbirine yakındır. Ancak pruritus, ekzemalar, bakteriyel hastalıklar, prekanseröz lezyonlar ve maling neoplazilerin yaşla artma eğiliminde olduğu gözlenmiştir. Prekanseröz lezyonların ve malign neoplazilerin yaşla birlikte artması tahmin edilebilir. Ancak geriatrik hastalarda daha yaşlı gruplarda poliklinik hizmetlerinden yararlanmanın zorluğu da düşünüldüğünde daha ciddi hastalıkların ön planda olacağı da akla getirilmelidir.

Geriartik hastalarda mevsimlere göre hastalık gruplarına bakıldığında kserozis ve pruritusun ilkbahar-yaz mevsimlerinde azaldığı; fungal deri hastalıkları, akneiform hastalıklar ve fotosensitif dermatozların ilkbahar-yaz aylarında arttığı tespit edildi. Ultraviyole ile tetiklenen fotosensitif hastalıkların ve yaşlılarda en sık görülen akneiform hastalık olan akne rozasenin ilkbahar-yaz aylarında artması beklenmektedir. Artan nem ve sıcaklıkla beraber yaz aylarında fungal infeksiyonların artışı da kaçınılmazdır.

\section{Sonuç}

Yaşlı popülasyonla ilgili yapılacak epidemiyolojik çalışmalar geriatrik yaş grubu hastalara verilecek sağlık hizmetlerinin planlanmasında ve koruyucu sağlık hizmetlerinin geliştirilmesinde yol gösterici olacaktır. Bu amaçla çalışmamız da yaşlı hastaların cilt sorunları çeşitli gruplar halinde toplanıp

\section{Tablo 5. Yaşlı hastalarda mevsimlere göre cilt hastalıklarının dağılımı}

\begin{tabular}{|c|c|c|c|c|c|c|c|c|}
\hline \multirow[t]{2}{*}{ Hastalık grubu } & \multicolumn{2}{|l|}{ Kış } & \multicolumn{2}{|c|}{ Illkbahar } & \multicolumn{2}{|l|}{ Yaz } & \multicolumn{2}{|c|}{ Sonbahar } \\
\hline & $\mathbf{n}$ & $\%$ & $\mathbf{n}$ & $\%$ & $\mathbf{n}$ & $\%$ & $\mathbf{n}$ & $\%$ \\
\hline Kserozis & 32 & 5,6 & 11 & 1,5 & 5 & 0,7 & 52 & 7,1 \\
\hline Pruritus & 98 & 17,0 & 88 & 11,7 & 67 & 9,9 & 96 & 13,1 \\
\hline Ekzemalar & 117 & 20,3 & 140 & 18,6 & 140 & 20,8 & 164 & 22,4 \\
\hline Viral deri hastalıkları & 33 & 5,7 & 47 & 6,2 & 36 & 5,3 & 33 & 4,5 \\
\hline Bakteriyel deri hastalkları & 21 & 3,7 & 31 & 4,1 & 25 & 3,7 & 32 & 4,4 \\
\hline Fungal deri hastalıkları & 85 & 14,8 & 146 & 19,4 & 136 & 20,2 & 126 & 17,2 \\
\hline Paraziter deri hastalıkları & 8 & 1,4 & 15 & 2,0 & 15 & 2,2 & 20 & 2,7 \\
\hline Vezikülobüllöz hastalıklar & 3 & 0,5 & 6 & 0,8 & 6 & 0,9 & 6 & 0,8 \\
\hline Akneiform hastalıklar & 14 & 2,4 & 26 & 3,4 & 18 & 2,7 & 15 & 2,1 \\
\hline Kutane lenfomalar & 9 & 1,6 & 10 & 1,3 & 7 & 1,0 & 3 & 0,4 \\
\hline Eritemli-skuamlı hastalıklar & 46 & 8,0 & 55 & 7,3 & 41 & 6,1 & 42 & 5,7 \\
\hline Benign neoplazi ve nevüsler & 14 & 2,4 & 16 & 2,1 & 34 & 5,0 & 27 & 3,7 \\
\hline Malign neoplaziler & 9 & 1,6 & 18 & 2,4 & 15 & 2,2 & 9 & 1,2 \\
\hline Prekanseröz lezyonlar & 25 & 4,3 & 35 & 4,6 & 26 & 3,9 & 23 & 3,1 \\
\hline Bağ dokusu hastalıkları & 4 & 0,7 & 6 & 0,8 & 4 & 0,6 & 2 & 0,3 \\
\hline Saç hastalıkları & 2 & 0,3 & 0 & 0,0 & 1 & 0,1 & 2 & 0,3 \\
\hline Tirnak hastalıkları & 1 & 0,2 & 2 & 0,3 & 3 & 0,4 & 1 & 0,1 \\
\hline Ürtiker ve anjiyoödem & 17 & 3,0 & 33 & 4,4 & 27 & 4,0 & 27 & 3,7 \\
\hline Vasküler hastalıklar & 7 & 1,2 & 14 & 1,9 & 12 & 1,8 & 7 & 1,0 \\
\hline Fotosensitif dermatozlar & 0 & 0,0 & 3 & 0,4 & 5 & 0,7 & 1 & 0,1 \\
\hline Behçet Sendromu & 0 & 0,0 & 3 & 0,4 & 2 & 0,3 & 1 & 0,1 \\
\hline Oral mukoza hastalıkları & 3 & 0,5 & 6 & 0,8 & 5 & 0,7 & 3 & 0,4 \\
\hline Fiziksel etkenlere bağlı dermatozlar & 8 & 1,4 & 26 & 3,4 & 15 & 2,2 & 21 & 2,9 \\
\hline Pigmentasyon bozuklukları & 1 & 0,2 & 10 & 1,3 & 7 & 1,0 & 2 & 0,3 \\
\hline Kutanöz ilaç reaksiyonları & 3 & 0,5 & 1 & 0,1 & 7 & 1,0 & 4 & 0,5 \\
\hline Diğer & 15 & 2,6 & 6 & 0,8 & 15 & 2,2 & 12 & 1,6 \\
\hline Toplam & 575 & 100 & 754 & 100 & 674 & 100 & 731 & 100 \\
\hline
\end{tabular}


analiz edilmeye çalışılmıştır. Ancak araştırmanın retrospektif olması ve sadece polikliniğe başvuran hastaları temel alması çalışmayı kısıtlamaktadır. Toplum temelli prospektif epidemiyolojik çalışmalar bu konuda daha faydalı olacaktır.

\section{Kaynaklar}

1. Türkiye istatistik kurumu: Türkiye istatistik yıllığı 2012. Devlet istatistik Enstitüsü Matbaası. Ankara 2012;27-71.

2. Mouton CP, Bazaldim OV, Pierce B, Espino DV. Common infections in older adults. Am Fam Physician 2001;63:257-68.

3. Laube S. Skin infections and ageing. Ageing Res Rev 2004;3:69-89.

4. Elgart ML. Skin infections and infestations in geriatric patients. Clin Geriatr Med 2002;18:89-101.

5. Kökçam I, Dilek N. Yaşlı hastalarda görülen deri hastalıkları. Turkish Journal of Geriatrics 2007;10:113-6.

6. Kılınç I, Ünal, Ceylan C, Özdemir F. Geriatrik hastalarda deri bulguları. Turkish Journal of Geriatrics 2002;5:103-6.

7. Baykal Y, Karaduman A, Bükülmez G. Yaşlı hastalarda deri sorunları. Turkish Journal of Geriatrics 1999;2:156-9.
8. Tüzün Y, Engin B. Yaşlılarda görülen dermatozlar. Dermatose 2004;3:44-56

9. Davis $\mathrm{G}$, Luggen $A$. Geriatric nurse practitioner care guidelines: pruritus and xerosis in the elderly person. Geriatr Nurse 2003;24:247-8.

10. Yalcin B, Tamer E, Toy GG, et al. The prevalence of skin diseases in the elderly: analysis of 4099 geriatric patients. Int J Dermatol 2006;45:672-6.

11. Havlik NL, Fitzpatrick TB, Kligman AM, Kligman LU. Ge-riatric dermatology. In: Freedberg IM, Eisen AZ, WolffK, Austen KF, Goldsmith LA, Katz SI, Fitzpatrick TB (eds). Fitzpalrick's Dermatology in General Medicine, 5th ed, New York, McGraw-Hill,I 999, vol 2, p 1707-1716.

12. Demirseren DD, Emre S, Ateşkan Ü, Metin A. Geriatri poliklinik hastalarında saptanan deri bulgularının prospektif analizi. Turkish Journal of Geriatrics 2010;13:87-91.

13. Kılıç A, Gül Ü, Aslan E, Soylu S. Dermatological findings in the senior population of nursing homes in Turkey. Archives of Geronyology and Geriatrics 2008;47:93-8.

14. Şaşmaz S, Çelik H, Ekerbiçer Ç, Çetinkaya A. Yaşılıarda deri hastalıkları. Turkish Journal of Geriatrics 2003;6:51-4.

15. Mutasim DF, Anhalt GJ. Bullous diseases in the elderly. Clin Geriatr Med 2002;18:43-58. 